
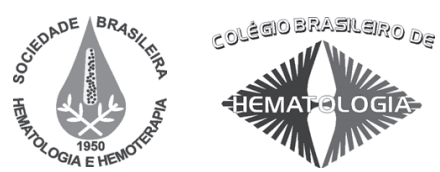

Carta ao Editor / Letter to Editor

\section{Transplante de células-tronco de doador não aparentado com sucesso após transplante de células de cordão umbilical não aparentado em paciente com leucemia linfocítica aguda. À procura do efeito enxerto versus leucemia}

Successful stem cell transplantation from an
unrelated donor after an unrelated cord blood
transplantation in an acute lymphocytic
leukemia patient: Searching for the graft
versus leukemia effect

Nelson Hamerschlak ${ }^{l}$

Fabio P. S. Santos ${ }^{2}$

José Mauro Kutner ${ }^{2}$

Andreza A. F. Ribeiro ${ }^{2}$

Marcos de Lima $^{5}$

${ }^{1}$ Head of Hematology Department - Hospital Albert Einstein, São Paulo-SP - Brazil.

${ }^{2}$ Bone Marrow Transplantation Unit, Hospital Israelita Albert Einstein, São Paulo-SP - Brazil.

${ }^{3}$ Department of Stem Cell Transplantation and Cell Therapy, M. D. Anderson Cancer Center, Houston, Texas, USA

\section{To Editor}

The only curative option for patients with acute lymphoblastic leukemia (ALL) that relapse after the initial treatment is allogeneic stem cell transplantation (allo HSCT). ${ }^{1}$ If cord blood (CB) is the source of stem cells for the first transplant, no hematopoietic progenitor cells or donor lymphocytes are available for a second transplant or for immunologic manipulations.

A 19-year old female patient was diagnosed with pro-B acute lymphoblastic leukemia (Pro-B ALL) in October 1997. The immunophenotype was CD34+, CD19+, CD22+, CD79a+, CD10-, cIgM-. Cytogenetics was diploid. Chemotherapy (GMALL02/84 protocol) was started, and she entered a complete remission (CR) within four weeks. Consolidation consisted of high-dose cytarabine, with maintenance for two years. Two years after the end of treatment, the patient relapsed, and was salvaged successfully with the HyperCVAD protocol.
No matched, related donors were available, but a $6 / 6$ HLA matched CB unit was identified (intermediate for HLA$\mathrm{A}$ and $-\mathrm{B}$, and high-resolution for HLA-DRB1), with total nucleated cell count of $3.14 \times 10^{7} / \mathrm{kg}$. Conditioning consisted of cyclophosphamide $60 \mathrm{mg} / \mathrm{kg}$ once daily (days -6 and -5 ) and fractionated total-body irradiation (1200cGy in six fractions, days $-4,-3$ and -2 ). Graft versus host disease (GVHD) prophylaxis was cyclosporine $5 \mathrm{mg} / \mathrm{kg}$ in two doses daily (starting on day -2) and short-course methotrexate $\left(15 \mathrm{mg} / \mathrm{m}^{2}\right.$ on day +1 , and $10 \mathrm{mg} / \mathrm{m}^{2}$ on days $+3,+6$ and +11 ). Neutrophils and platelets engraftment occurred on transplant days 14 and 24 . Day +30 chimerism was $100 \%$ done by fluorescent in situ hybridization (FISH) analysis for the Y chromosome. There was no acute or chronic GVHD.

A second relapse was diagnosed 32 months posttransplant. Hyper-CVAD was used (no response) and subsequently, high-dose cytarabine and mitoxantrone, with a third CR. Complications included cryptococcal pneumonia.

A 10/10 HLA matched unrelated donor was identified (intermediate for HLA-A, -B and C, and high-resolution for HLA-DRB1 and -DQB1). Busulfan $130 \mathrm{mg} / \mathrm{m}^{2}$ (on days $-6,-5$, -4 and -3 ) and fludarabine $40 \mathrm{mg} / \mathrm{m}^{2}$ (on days $-6,-5,-4$ and -3 ) were administered, both once daily. ${ }^{2}$ GVHD prophylaxis was done with tacrolimus (dose adjusted to maintain whole blood through levels between 5 and $15 \mathrm{ng} / \mathrm{ml}$ ), and mini-dose methotrexate $\left(5 \mathrm{mg} / \mathrm{m}^{2}\right.$ on days $+1,+3,+6$ and +11$)$. The peripheral blood stem cell graft contained a total dose of CD34+ cells of $2.35 \times 10^{6} / \mathrm{kg}$. Neutrophil and platelet engraftment occurred on days +20 and +62 . The patient developed grade II acute and extensive chronic GVHD; multiple episodes of citomegalovirus reactivation, and pulmonary aspergillosis, but recovered fully. She is alive, in good performance status and in CR 30 months post-second transplant.

There is no established treatment for ALL relapsing after allo HSCT. The main options are to perform a second allo HSCT or the use of immunotherapy in the form of donor lymphocyte infusions, but results are usually poor, due to low efficacy of salvage chemotherapy that precedes transplant, high toxicities rates of the conditioning regimen, and the relative insensitivity of ALL to the graft-versusleukemia (GVL) effect. ${ }^{3}$ Duration of remission after the first transplant, achievement of CR before the second procedure, age, and type of leukemia significantly influence the success of a second allo HSCT. ${ }^{3}$

Our patient received a CB transplant initially, and no cells were available for treatment of relapse (as expected). There are few reports of successful second allo SCT in this context. ${ }^{4}$ We only had time to search and secure an unrelated donor because the patient entered a third CR with Ara-Cbased chemotherapy. ${ }^{5}$

There is no established conditioning regimen for a second allo HSCT in patients with ALL, ${ }^{6}$ especially after failure of TBI-based regimens. Reduced-intensity conditioning can be recommended, but reductions in dose intensity can be associated with increased likelihood of failure due to relapsed disease. We therefore chose to use ablative doses of 
intravenous busulfan in combination with fludarabine, ${ }^{2}$ hypothesizing that it would provide enough myeloablation and immunosuppression while minimizing the risk of toxicity.

The patient developed chronic GVHD after the second transplantation, which likely contributed to the prolonged disease-free survival enjoyed so far. Even though it is largely believed that ALL is less responsive to the GVL effect, ${ }^{7}$ the development of chronic GVHD is associated with long term disease-free survival in advanced ALL, showing that GVL is important for the control of this disease. ${ }^{8}$

Second ablative transplant from unrelated donor may be successfully offered to selected patients with ALL relapsing after $\mathrm{CB}$ transplants. The role of the GVHD/GVL phenomena was particularly important in this case.

\section{Resumo}

Segundo transplante homólogo é uma opção terapêutica para pacientes com leucemia linfoblástica aguda (LLA) que têm recorrência após o primeiro transplante. Entretanto, para pacientes sem parentes compativeis, pode ser dificil encontrar um segundo doador não aparentado. Uma moça de 19 anos com proB LLA desde 1997 recebeu quimioterapia e entrou em remissão completa $(R C)$ em quatro semanas. Alta dose de citarabina foi mantida por dois anos. Dois anos após o final do tratamento, a paciente apresentou recorrência, e recebeu o protocolo HyperCVAD (ciclofosfamida, doxorrubicina, vincristina e dexametasona). Um doador de cordão umbilical compativel 6/6 foi identificado e usado. Não havia sinais de doença do enxerto versus hospedeiro (DEVH) aguda. Segunda recorrência foi diagnosticada 32 meses após o transplante. O tratamento consistiu novamente no protocolo Hyper-CVAD), sem resposta, e, subsequentemente, citarabina de alta dosagem com mitoxantrona de alta dosagem, resultando numa terceira RC. Um doador não aparentado, 10/10 HLA compativel, foi identificado. A despeito da terapia profilática, a paciente desenvolveu DEVH aguda e crônica e múltiplos episódios de infecções, mas se recuperou completamente. Ela está viva, em boa performance e em remissão completa 24 meses após o segundo transplante. Houve tempo para encontrar um doador não aparentado após o transplante inicial de células de cordão apenas porque a paciente entrou numa terceira $R C$ após quimioterapia. Segundo transplante de célula-tronco alogênico, de doador não aparentado, pode ser oferecido a pacientes selecionados após transplante de células de cordão, especialmente após recorrência, sem DEVH elou o fenômeno enxerto versus leucemia. Rev. Bras. Hematol. Hemoter. 2009;31(4):293-294.

Palavras-chave: Transplante de células-tronco de sangue do cordão umbilical; transplante de células-tronco hematopoéticas; recidiva; leucemia linfoide.

\section{References}

1. Fielding AK, Richards SM, Chopra R, Lazarus HM, Litzow MR, Buck G, et al. Outcome of 609 adults after relapse of acute lymphoblastic leukemia (ALL); an MRC UKALL12/ECOG 2993 study. Blood. 2007;109(3):944-50.

2. de Lima M, Couriel D, Thall PF, Wang X, Madden T, Jones R, et al. Once-daily intravenous busulfan and fludarabine: clinical and pharmacokinetic results of a myeloablative, reduced-toxicity conditioning regimen for allogeneic stem cell transplantation in AML and MDS. Blood. 2004;104(3):857-64.

3. Bosi A, Laszlo D, Labopin M, Reffeirs J, Michallet M, Gluckman E, et al. Second allogeneic bone marrow transplantation in acute leukemia: results of a survey by the European Cooperative Group for Blood and Marrow Transplantation. J Clin Oncol. 2001;19 (16):3675-84.

4. Kai T, Kimura H, Shiga Y, Mineishi S, Yoshihara S, Ogawa H, et al. Philadelphia chromosome-positive acute lymphoblastic leukemia rescued with a second allogeneic stem cell transplantation from a haploidentical mother after relapse following cord blood transplantation. Int J Hematol. 2004;80(5):453-7.

5. Ludwig WD, Rieder H, Bartram CR, Heinze B, Schwartz S, Gassmann $\mathrm{W}$, et al. Immunophenotypic and genotypic features, clinical characteristics, and treatment outcome of adult pro-B acute lymphoblastic leukemia: results of the German multicenter trials GMALL 03/87 and 04/89. Blood. 1998;92(6):1898-909.

6. Radich JP, Sanders JE, Buckner CD, Martin PJ, Petersen FB, Bensinger $\mathrm{W}$, et al. Second allogeneic marrow transplantation for patients with recurrent leukemia after initial transplant with total-body irradiation-containing regimens. J Clin Oncol. 1993;11(2):304-13.

7. Kolb HJ, Schmid C, Barrett AJ, Schendel DJ, et al. Graft-versusleukemia reactions in allogeneic chimeras. Blood. 2004;103(3): 767-76.

8. Gassas A, Ishaqi MK, Afzal S, Dupuis A, Doyle J. Outcome of haematopoietic stem cell transplantation for paediatric acute lymphoblastic leukaemia in third complete remission: a vital role for graft-versus-host-disease/ graft-versus-leukaemia effect in survival. Br J Haematol. 2008;140(1):86-9.

Avaliação: Editor e dois revisores externos

Conflito de interesse: sem conflito de interesse

Recebido: 26/02/2009

Aceito: $12 / 03 / 2009$

Hospital Albert Einstein

Correspondência: Nelson Hamerschlak

Bone Marrow Transplantation Unit, Hospital Israelita Albert Einstein Av. Albert Einstein, 627 - Building Manoel T. Hidal - Room 1203 05652-000 - São Paulo-SP - Brazil

E-mail:hamer@einstein.br 